\title{
Firm Internal Factors and Competitive Position of Export-oriented Companies in Pakistan: Evidence from the Textile Sector
}

\author{
Syed Zagham Abbas \\ Department of Business Administration, University of Punjab Jhelum campus, Pakistan \\ E-mail: zagham7722002@ gmail.com
}

\begin{abstract}
Syed Amad Nadeem
Department of Business Administration, University of Punjab Jhelum campus, Pakistan E-mail: amadnad@gmail.com
\end{abstract}

Received: November 29, 2017 Accepted: December 14, 2018 Published: June 20, 2018 doi:10.5296/ber.v8i3.13297 URL: https://doi.org/10.5296/ber.v8i3.13297

\begin{abstract}
Different internal factors that affect the competitive position of export-oriented firms in Pakistan have been investigated in this paper. The sample is based on firms which are involved in the textile trade and are listed on Pakistan Stock Exchange. Results of empirical analysis show that return on assets has negative relation with leverage. Similarly, the results of our empirical analysis show that size has a negative relation with ROE. Liquidity has a positive relation with ROA, whereas growth and exports do not have any observable effect on competitive position of a firm.
\end{abstract}

Keywords: Firm competitiveness, Export, Strategy, Competitive advantage, Return on equity

\section{Introduction}

Competitiveness is namely the competencies, power and abilities of a firm. Other competitors are prevented from having access to it or less than the firm (Iskandri, Miri, Gholami, Reza and Nia , 2015). According to the Merium Webster dictionary, competitiveness is "inclined to or suited to compete." According to the five forces model proposed by Michael porter, there are five forces which influence the competitive position of a firm in an industry. While intensive competition from porters five forces model introduces the structure of the industry and competitive relationships, there are other factors which can affect the competitive 
position of a firm. These other factors can be characterized as internal and external factors. Competitiveness can be considered as an outcome (Akben-Selcuk, 2016). Performance is an important firm-level outcome. There are mainly three dimensions to firm performance: the company's productivity, the firm's profitability, and lastly the firm's market premium or firm's ability to cover its costs. We adopt a static outcome-based approach in this paper. Accordingly, the focus of this paper is to focus on internal factors which affect the financial performance of a firm. Good financial performance indicates better competitiveness because higher profitability is reflective of higher sales and production.

This era is marked by globalization- a phenomenon characterized by improved growth, elimination of trade barriers, low cost of communication and spread of technology. Globalization is making it easier for companies to do business across borders. As such, companies are facing intense competition both from local as well as foreign companies. Intense competition in local and international markets requires firms to improve their competitiveness. (Liargovas and Skandalis, 2008). This improvement in competitiveness is not only beneficial for the small firms but it also has the potential to improve the overall competitiveness of an economy.

We find that, even though there is abundance of literature pertaining to competitiveness, yet little work has been done on what shapes competitiveness for firms in emerging markets. The purpose of this study is to define a framework for competitiveness, as defined by financial performance of a firm, and to identify factors which impact the financial performance of a firm. Of particular interest is the financial performance of those firms which sell products internationally.

We have drawn our sample from the largest industrial sector in Pakistan; namely the textile sector. The textile sector is the biggest contributor to the industrial sector in Pakistan, accounting for $60 \%$ of total exports of the country and contributing US\$. 13.9 billion to the economy in 2013. However over the past decade growth in textile sector has remained stagnant because of different reasons. The once booming textile sector is not showing signs of growth.

We have restricted our study to one industrial sector to limit the effects of industry-specific factors.

\section{Problem statement}

What are the determinants of firm competitiveness of export-oriented firms?

\section{Objectives:}

1) To identify factors which increase or decrease the competitive position of an export-oriented firm

2) To analyze which factors are most important in determining competitive position of a firm

3) To provide a framework for assessing the competitive position of a firm 
Return on assets, a ratio which measures a company's ability to use its assets, is used to measure a firm's financial performance. Similarly, return on equity and gross profit margin are used as proxies for firm performance and as dependent variables whereas firm size, liquidity and leverage are treated as independent variables.

\section{Literature review}

\subsection{Firm Size}

Firm size appears to be an important factor in predicting firm performance. Firm size increases firm performance because large firms with large size have the capacity to expand and increase production (Bashir and Abbas et. al) (2013). Similarly large firms have more staff and access to a better information system. Banchuenvijit (2012) shows that there is a negative and significant relationship between firm size and ROA; and that there is a negative and insignificant relationship between firm size and ROE. Moreover large firms are followed by a number of analysts who confirm or disconfirm their expectations of a company's future economic performance ( Al-Malaji, Alamro \& Al-Soub 2012). On the other hand, Wung, 2009, shows firm performance can increase with size. However, firm size does not always impact a firm's performance in a positive way.

\section{$2.2 R \& D$}

Ghaffar et al. (2014) show an insignificant relationship between ROA and R\&D. Yet they show that firm performance increases with $R \& D$. Hence firms should invest heavily in $R \& D$, especially during the innovation stage. To achieve the desired objective, the firm should not invest below a specified minimum level of R\&D (Wung (2009)). Growth seems to have a significant impact on firm performance. Bashir et al (2013) show that growth does not have a significant impact on firm performance. They show that there is a negative and insignificant relationship between growth and firm performance. However, Bashir, Abbas and Manzoor (2013) show that a positive relationship exists firm performance and growth in the food sector in Pakistan.

The impact of R\&D activities is contingent on the policies adopted by the firm. Firm policies which utilize $R \& D$ activities and capital accumulation are found to have a positive effect on efficiency. In addition to $R \& D, R \& D$ intensity also seems to have an effect on efficiency. Investments in capital and $R \& D$ are particularly important for highly technological firms. Changes in R\&D investments affect both high and low technology firms, but the effect is more elastic for high technology firms. Technology firms which invest more in R\&D are more efficient as compared to firms which invest less in R\& D. (Kumbhakar et al.(2010)).

\subsection{Growth}

Kozak (2011) studies insurance companies in Poland. He shows that increase in gross premiums leads to increase in profitability and efficiency- measures which are directly linked with firm performance. This is because growth in size of non-insurance companies improves overall profitability of those companies. Secondly, growth in the size of medium-sized insurance companies makes them cost-efficient. Alternatively, the effect of the scale of 
company operations on profitability can also be attributed to the fact that insurance companies in Poland have specialized product offerings. Hence, both growth and size affect profitability of a company. Yu, Chen and Hsieu (2008) show that growth has a significant and positive effect on banks (Keiretsu) in Japan.

\subsection{Leverage}

Low leverage might be beneficial for a firm because highly leveraged firms lose market share because of competition from less leveraged firms. Highly leveraged firms have limited capacity to invest capital in assets which in turn leads to depressed firm value. (Al Malaji et al., 2012). But leverage is found to have significant relationship with ROA in good economic times. This is because leverage is less risky in times during times of economic growth and more risky during times of slow economic growth. While leverage increases costs of bankruptcy, investments in risky assets can also increase return for shareholders.

\subsection{Liquidity}

Al-Malaji, Alamro and Al-Soub ( 2012) show that Liquidity has a significant impact on financial performance of insurance companies. Similarly Xu and Banchuenvijit (2012) show that liquidity positively impacts financial performance of a company. Firms with high liquidity show reduced risk and hence better performance However, Bashir et al. (2013) show that liquidity does not influence financial performance of companies in the food industry in Pakistan.

\subsection{Exports}

Exporting firms show higher productivity than non-exporting firms. Similarly, exporting firms show better economic indicators. This is because exporting firms are better able to increase production standards and adopt technology from overseas. Exporting increases capacity utilization by expanding sales( Park, Yang, Shi and Jiang(2009)). Moreover performance differences between export-oriented and domestic market participants show that performance is greater for entering exporters at the time they enter exporting.(Farinas and $\operatorname{Marcos}(2005))$.

\section{Data and Methodology}

To collect data about factors affecting firm competitiveness we gather a sample of companies from Karachi Stock Exchange. To counter the effects of industry-specific factors on firm financial performance, the study focuses on textile sector only. Moreover the textile industry, inspite of being the largest industry in Pakistan, has been characterized by low profitability and solvency over the past decade. The final sample consists of 38 firms from the textile sector. Data is collected for every firm in the sample for the six year period beginning 2012 and ending 2016. The data is collected from published financial statements.

\subsection{Variables}

We will use financial performance of the firm as a measure of competitiveness of a firm. So competitive position of a firm is measured with three financial ratios, return on assets, return 
on equity and gross profit margin. The first of these, return on assets, is the most widely used measure of financial performance. First developed by Dupont, the return on assets measures a firm's ability to utilize its assets. Gross profit margin is a ratio which measures the profitability of a firm. It is that proportion of revenue leftover after accounting for cost of goods sold. It is independent of inflationary bias. The last of these, return on equity, in fact measures how much money a company earns relative to its total equity. It is one of the most important profitability measures. It shows the ability of a firm to generate cash internally.

We can show that financial performance is a function of leverage, liquidity, size and growth based on the literature we have studied. As such, the above relationship is estimated using regression analysis. Each measure of financial performance is regressed against the explanatory variables. Because the data is cross-sectional time series in nature, we use panel data analysis to analyze the relationship between the dependent variables and explanatory variables. The equation used is of the following format:

$$
\begin{gathered}
\mathrm{Y}_{i t}=\mathrm{b}_{0+} \mathrm{b}_{1} \mathrm{X}_{i t}+\mathrm{w}_{i t} \\
\mathrm{w}_{i t=} \varepsilon_{i}+u_{i t}
\end{gathered}
$$

Where $\mathrm{Y}_{i t}$ is the measure of firm performance, $\mathrm{b}_{0}$ and $\mathrm{b}_{1}$ are coefficients to be estimated. And $\varepsilon_{i}$ individual-specific or cross-section component, and $u_{i t}$ is combination of cross-section and time-series effects. Hausman test, a form of chi-square test, is used to decide whether a random effects model or fixed effects model is more appropriate. The null hypothesis underlying the test is that ECM and FCM estimators do not differ substantially from each other. Moreover, White's test will performed on our sample to test for heteroscedasticity.

More specifically, the equations to be used can be expressed as:

$$
\begin{aligned}
& \text { ROAit }=\beta_{1} \text { GROWTHit }+\beta_{2} \text { LEVERAGEit }+\beta_{3} \text { LIQUIDITYit }+\beta_{4} \text { SIZEit }+u_{i t} \\
& \mathrm{ROE}_{\mathrm{it}}=\beta_{5} \text { GROWTHit }+\beta_{6} \text { LEVERAGEit }+\beta_{7} \text { LIQUIDITYit }+\beta_{8} \mathrm{SIZEi}+\mathrm{u}_{\mathrm{it}} \\
& \mathrm{GM}_{\mathrm{it}}=\beta_{9} \text { GROWTHit }+\beta_{10} \text { LEVERAGEit }+\beta_{11} \text { LIQUIDITYit }+\beta_{12} \mathrm{SIZEi}+\mathrm{u}_{\mathrm{it}}
\end{aligned}
$$

GMit $=$ Gross margin of firm i at time $\mathrm{t}$

ROAit $=$ return on assets of firm $\mathrm{I}$ at time $\mathrm{t}$

$R O E_{i t}=$ return on equity of firm $\mathrm{I}$ at time $\mathrm{t}$

GROWTHit $=$ Growth rate of Firm i at time $\mathrm{t}$

LEVERAGEit $=$ Total debt divided by total assets for firm $\mathrm{i}$ at time $\mathrm{t}$

LIQUIDITYit $=$ Current assets/current liabilities for firm $\mathrm{i}$ at time $\mathrm{t}$

SIZEit $=$ Log of total assets

$u_{i t=}$ error term denoting a combination of cross-section and time-series effects

The betas denote constant terms. 


\section{Results and Discussion}

This section will, beginning with descriptive statistics, analyze the results of the regression analysis. Table 1 shows that Gross profit margin has increased an average of $72.5 \%$ over the year and its deviation from the mean is 3.48. Growth has decreased by an average of $29.4 \%$ and its deviation from the mean is 3.64. Leverage has increased an average of $22 \%$ over the year and its deviation from the mean is 10.74 . ROA has increased an average of $40 \%$ over the year and its deviation from the mean is 2.43 . ROE has increased an average of $14 \%$ over the year and its deviation from the mean is 0.45 . Similarly, the descriptive statistics show that size has increased an average of $6.4 \%$ over the year and its deviation from the mean is 3.8 . In the sample, nearly $90 \%$ of the firms earn income from abroad. Results of our analysis show that only two of the variables, liquidity and leverage, are statistically significant as measured by the ROA. The results show that leverage is negatively related to ROA and liquidity is positively related to ROA. Hence, as the return on assets increases, the profitability or financial performance of a firm deteriorates. However, as the level of liquidity increases the profitability of a firm increases. Results of the second regression analysis show that as size of a firm increases, return on equity deteriorates. Other independent variables do not have a significant effect on return on equity. Hence, increases in liquidity or leverage or growth do not seem to either increase or decrease return for shareholders. Results of the third regression analysis show that none of the independent variables have a significant effect on gross margin. Results of the White test show that heteroscedasticity is not present.

The empirical results, overall, suggest that different firm-specific factors can influence the financial as well as competitive position of Pakistani firms, particularly those in the textile sector.

Table 1.

\begin{tabular}{|c|c|c|c|c|c|c|c|c|c|c|}
\hline & EXPORTS & FIRM & GM & GROWTH & LEVERAGE & LLQUIDITY & RESID & ROA & ROE & SIZE \\
\hline Mean & 1.000000 & NA & 0.725255 & -0.294994 & 2.201763 & 2.100313 & NA & 0.405356 & 0.170394 & 6.413211 \\
\hline Median & 1.000000 & NA & 0.096000 & 0.009000 & 0.370000 & 0.890000 & NA & 0.048000 & 0.092100 & 7.360000 \\
\hline Maximum & 1.000000 & NA & 28.48000 & 16.70000 & 123.0000 & 123.0000 & NA & 22.00000 & 3.840000 & 11.03000 \\
\hline Minimum & 1.000000 & NA & -1.116000 & -33.00000 & -19.70000 & -19.01000 & NA & -0.990000 & -0.870000 & 0.010100 \\
\hline Std. Dev. & 0.000000 & NA & 3.488665 & 3.644054 & 10.74723 & 10.16886 & NA & 2.430300 & 0.454493 & 3.847523 \\
\hline Skewness & NA & NA & 6.165216 & -4.821325 & 9.303446 & 10.90907 & NA & 7.716203 & 5.797752 & -0.787079 \\
\hline Kurtosis & NA & NA & 42.45376 & 49.62048 & 104.8118 & 130.7249 & NA & 63.82161 & 43.96364 & 2.022837 \\
\hline Jarque-Bera & NA & NA & 11034.96 & 14637.49 & 69180.82 & 108433.4 & NA & 25429.22 & 11705.57 & 22.17031 \\
\hline Probability & NA & NA & 0.000000 & 0.000000 & 0.000000 & 0.000000 & $N A$ & 0.000000 & 0.000000 & 0.000015 \\
\hline Sum & 155.0000 & NA & 112.4145 & -45.72400 & 341.2732 & 325.5485 & NA & 62.83013 & 26.41109 & 994.0477 \\
\hline Sum Sq. Dev. & 0.000000 & NA & 1874.301 & 2044.986 & 17787.44 & 15924.48 & NA & 909.5792 & 31.81090 & 2279.728 \\
\hline Observations & 155 & 0 & 155 & 155 & 155 & 155 & 0 & 155 & 155 & 155 \\
\hline
\end{tabular}




\begin{tabular}{|c|c|c|c|c|}
\hline \multicolumn{5}{|l|}{ ROA } \\
\hline Variable & Coefficient & Std. Error & t-Statistic & Prob. \\
\hline $\mathrm{C}$ & -0.248404 & 0.682138 & -0.364155 & 0.7164 \\
\hline GROWTH & 0.016778 & 0.057984 & 0.289354 & 0.7728 \\
\hline LEVERAGE & -0.148353 & 0.077055 & -1.925275 & 0.0566 \\
\hline LIQUIDITY & 0.136366 & 0.081216 & 1.679050 & 0.0957 \\
\hline \multirow[t]{2}{*}{ SIZE } & 0.108984 & 0.101677 & 1.071864 & 0.2859 \\
\hline & \multicolumn{2}{|c|}{ Effects Specification } & & \\
\hline \multicolumn{5}{|c|}{ Cross-section fixed (dummy variables) } \\
\hline R-squared & 0.217271 & \multicolumn{2}{|c|}{ Mean dependent var } & 0.405356 \\
\hline Adjusted R-squared & -0.004502 & \multicolumn{2}{|c|}{ S.D. dependent var } & 2.430300 \\
\hline S.E. of regression & 2.435765 & & & \\
\hline \multirow[t]{2}{*}{ Prob(F-statistic) } & 0.501913 & & & \\
\hline & & & & \\
\hline Dubin-Watson & 2.142569 & & & \\
\hline
\end{tabular}

\begin{tabular}{|c|c|c|c|c|}
\hline \multicolumn{5}{|l|}{ ROE } \\
\hline Variable & Coefficient & Std. Error & t-Statistic & Prob. \\
\hline $\mathrm{C}$ & 0.422720 & 0.096100 & 4.398767 & 0.0000 \\
\hline GROWTH & 0.002037 & 0.007533 & 0.270462 & 0.7872 \\
\hline LIQUIDITY & 0.000380 & 0.009204 & 0.041331 & 0.9671 \\
\hline LEVERAGE & -0.002060 & 0.008735 & -0.235776 & 0.8139 \\
\hline \multirow[t]{3}{*}{ SIZE } & -0.038668 & 0.011076 & -3.491080 & 0.0006 \\
\hline & \multicolumn{2}{|c|}{ Effects Specification } & & \\
\hline & & & S.D. & Rho \\
\hline \multicolumn{3}{|c|}{ Cross-section random } & 0.330319 & 0.5150 \\
\hline \multicolumn{3}{|c|}{ Idiosyncratic random } & 0.320557 & 0.4850 \\
\hline \multicolumn{3}{|c|}{ Dependent Variable: GM } & & \\
\hline \multicolumn{5}{|c|}{ Method: Panel EGLS (Cross-section random effects) } \\
\hline \multicolumn{5}{|c|}{\begin{tabular}{|l|l|l} 
Date: $11 / 04 / 17 \quad$ Time: $12: 24$ & \\
\end{tabular}} \\
\hline \multicolumn{5}{|c|}{ Sample: 20122016} \\
\hline \multicolumn{5}{|c|}{ Cross-sections included: 31} \\
\hline Variable & Coefficient & Std. Error & t-Statistic & Prob. \\
\hline $\mathrm{C}$ & 0.987285 & 0.609084 & 1.620935 & 0.1071 \\
\hline GROWTH & 0.005950 & 0.077042 & 0.077230 & 0.9385 \\
\hline LIQUIDITY & 0.106997 & 0.070937 & 1.508341 & 0.1336 \\
\hline LEVERAGE & -0.097254 & 0.067489 & -1.441024 & 0.1517 \\
\hline \multirow[t]{3}{*}{ SIZE } & -0.042237 & 0.081162 & -0.520395 & 0.6036 \\
\hline & \multicolumn{2}{|c|}{ Effects Specification } & & \\
\hline & & & S.D. & Rho \\
\hline \multicolumn{3}{|c|}{ Cross-section random } & 0.916868 & 0.0672 \\
\hline
\end{tabular}




\begin{tabular}{|l|l|l|l|}
\hline Weighted Statistics & \multicolumn{4}{|l|}{$\mid$} \\
\hline R-squared & 0.018924 & & 0.621890 \\
\hline Adjusted R-squared & -0.007238 & & 3.376002 \\
\hline S.E. of regression & 3.388197 & & 1721.982 \\
\hline Unweighted Statistics \\
\hline R-squared & 0.021050 & & 0.725255 \\
\hline Sum squared resid & 1834.846 & & 1.372499 \\
\hline
\end{tabular}

\begin{tabular}{|c|c|c|c|c|}
\hline \multicolumn{5}{|l|}{ GM } \\
\hline Variable & Coefficient & Std. Error & $\mathrm{t}$-Statistic & Prob. \\
\hline $\mathrm{C}$ & 0.987285 & 0.609084 & 1.620935 & 0.1071 \\
\hline GROWTH & 0.005950 & 0.077042 & 0.077230 & 0.9385 \\
\hline LIQUIDITY & 0.106997 & 0.070937 & 1.508341 & 0.1336 \\
\hline LEVERAGE & -0.097254 & 0.067489 & -1.441024 & 0.1517 \\
\hline \multirow[t]{3}{*}{ SIZE } & -0.042237 & 0.081162 & -0.520395 & 0.6036 \\
\hline & \multicolumn{2}{|c|}{ Effects Specification } & & \\
\hline & & & S.D. & Rho \\
\hline \multicolumn{3}{|c|}{ Cross-section random } & 0.916869 & 0.0672 \\
\hline \multicolumn{3}{|c|}{ Idiosyncratic random } & 3.416737 & 0.9328 \\
\hline
\end{tabular}

\begin{tabular}{|l|l|}
\hline \multicolumn{2}{|l|}{ Weighted Statistics } \\
\hline R-squared & 0.018924 \\
\hline Adjusted R-squared & -0.007238 \\
\hline S.E. of regression & 3.388197 \\
\hline Unweighted Statistics \\
\hline R-squared & 0.021050 \\
\hline Sum squared resid & 1834.846 \\
\hline
\end{tabular}

\section{Conclusion}

The purpose of this study is to investigate the different factors which can affect the competitive position of a firm, as measured by its financial performance. Financial performance was proxied by ROA, ROE and GM (gross profit margin). The study was focused solely on the textile sector of Pakistan- a developing country and an emerging economy. The financial performance of over 35 firms was analyzed from 2012 to 2016. This shows that multiple factors can have an effect on the competitive position of a firm.

The findings of this study indicate that leverage has a significant impact on a firm's financial performance. An increase in leverage negatively impacts a firm's financial performance. The 
finding is consistent with (Malaji et al., 2012). Similarly, our findings show that liquidity has a positive impact on financial performance of a firm. As liquidity increases, the current ratio of a firm increases. The finding is consistent with $\mathrm{Xu}$ and Banchuenvijit (2012). This implies that a firm should aim for a high liquidity position because this will enhance its financial performance and hence it's competitive position.

The results further indicate that size of a firm has a significant impact on financial performance of a firm. As the size of a firm increases, the return on equity decreases. Hence we can conclude that size alone does not lead to increased profitability.

In fact, smaller firms have a competitive advantage over larger firms. Other factors such as growth rate were found to have an insignificant effect on measures of firm financial performance. The results indicate that growth rate does not have any impact ROA and ROE. The weakness of relationship between ROA, ROE and growth rate implies that growth-oriented strategies do not necessarily enhance the competitive position of a firm.

We can conclude that financial performance of a firm is a good indicator of the competitive position of a firm and that several factors can influence the competitive position of a company. Managers should take a broader view of the competitive landscape the company operates in and should consider the several internal firm-specific factors as well as external factors when evaluating the financial position of firms. Many of these factors can either enhance or deteriorate the competitive position of a firm. Hence investors and managers alike need to be particularly conscious of factors like liquidity position of a firm, capital structure and size of a firm if they want to attain a competitive edge in an emerging economy like Pakistan.

\section{Limitations and future research}

The results obtained from this study were instrumental in explaining the association between competitive position of a firm or its financial position and the various firm-specific factors. However, the study suffers from some limitations. The study investigated only the impact of few firm-specific variables on firm competiveness. Hence further studies should attempt to analyze the impact of corporate governance, capital expenditure and other variables on firm performance. Secondly, this study focused on a single industry. Future research should analyze other industries or groups of industries. Thirdly, this study focused solely on one country. Future studies should analyze multiple emerging economies.

\section{References}

Almalaji, A. Y., Alamro, S. A., \& Al-Soub, Y. Z. (2012). Factors Affecting the Financial Performance of Jordanian Insurance Companies Listed at Amman Stock Exchange. Journal of Management Research, 4(2), 266-289.

Bashir, Z., Abbas, A., Manzoor, S., \& Akram, M. N. (2013). Empirical Investigation of the Factors Affecting Firm's Performance: a study Based on Food Sector of Pakistan. International SAMANM Journal of Finance and Accounting, 1(3), 11-23.

Burton, J. (1995). Composite strategy: the combination of collaboration and competition. 
Journal of General Management, 21(1), 1-23. https://doi.org/10.1177/030630709502100101

Capon, N., Farley, J. U., \& Hoenig, S. (1990). Determinants of financial performance: A meta-analysis. Manag. Sci., 36, 1143-1159. https://doi.org/10.1287/mnsc.36.10.1143

Dagog, D. W. (2014). Degree of Operating Leverage, Contribution Margin and the Risk-Return Profile of Emerging Companies: Evidence from Nigeria. International Journal of Economics and Finance, 6(12), 148-156. https://doi.org/10.5539/ijef.v6n12p148

Giovanis, E., \& Ozdamar, O. (2014). Facoltà di Economia, Università degli Studi di Verona. Determinants of Profitability: Evidence from US Firms. Unpublished work.

Gleason, K. C., Mathur, L. K., \& Mathur, I. (2000). The interrelationship between culture, capital structure and performance: Evidence from European Retailers. J. Bus. Res., 50, 185-191. https://doi.org/10.1016/S0148-2963(99)00031-4

Goddard, J., Tavakoli, M., \& Wilson, J. O. S. (2005). Determinants of profitability in European manufacturing and services: Evidence from a dynamic panel model. Appl. Financ. Econ., 15, 1269-1282. https://doi.org/10.1080/09603100500387139

Gurbuz, A. O., Aybars, A., \& Kutlu, O. (2010). Corporate governance and financial performance with a perspective on institutional ownership: Empirical evidence from Turkey. J. Appl. Manag. Account. Res., 8, 21-38

Kakani, R. K., Saha, B., \& Reddy, V. N. (2016). Determinants of Financial Performance of Indian Corporate Sector in the Post-Liberalization Era: An Exploratory Study. National Stock Exchange of India Limited, NSE Research Initiative Paper No. 5. 2001. Retrieved January 3, 2016 from http://ssrn.com/abstract=904983 (accessed on 3 January 2016).

Karabag, S. F., Lau, M. C. K., \& Suvankulov, F. (2014). Determinants of firm competitiveness: case of the Turkish textile and apparel industry. J. Text. Inst., 10, 1-11. https://doi.org/10.1080/00405000.2013.811787

Khan, W. A., Ghaffar, A., \& Khan, W. A. ( 2014). Impact of Research and Development on Firm Performance. International Journal of Accounting and Financial Reporting, 4(1), 357-367. https://doi.org/10.5296/ijafr.v4i1.6087

Kietels, C. (2016). Review of competiteveness frameworks. Retrieved 3 January 3, 2018 from

http://www.hbs.edu/faculty/Publication\%20Files/Review\%20of\%20Competitiveness\%20Fra meworks\%20_3905ca5f-c5e6-419b-8915-5770a2494381.pdf.Accessed on 28 February, 2018.

Krugman P. (1994). Competitiveness: A Dangerous Obsession. Foreign Affairs, 73(2). https://doi.org/10.2307/20045917

Krugman, P. (1999). The Role of Geography in Development, International Regional Science Review, 22(2). https://doi.org/10.1177/016001799761012307

Lalinsky, T. (2013). Firm Competitiveness Determinants: Results of a Panel Data Analysis. Retrieved January 3, 2016 from http://papers.ssrn.com/sol3/papers.cfm?abstract_id=2548947. 
Lipe, R., \& Kormendi, R. (1994). Mean reversion in annual earnings and its implications for security valuation. Rev. Quant. Finance Account, 4, 27-46.

https://doi.org/10.1007/BF01082663

Majumdar, S. K., \& Chhibber, P. (1999). Capital structure and performance: Evidence from a transition economy on an aspect of corporate governance. Public Choice, 98, 287-305. https://doi.org/10.1023/A:1018355127454

Mirza, S. A., \& Javed, A. (2013). Determinants of financial performance of a firm: Case of Pakistani stock market. J. Econ. Int. Finance, 5, 43-52. https://doi.org/10.5897/JEIF12.043

Nosa \& Ose (2010). Capital Structure and Corporate Performance in Nigeria: An empirical investigation. Journal Of Management Sciences, 1(1), 43-52.

Pervan, M., \& Visic, J. (2012). Influence of firm size on its business success. Croat. Oper. Res. Rev., 3, 213-223

Porter, M. (1979). How competitiveness forces shape strategy. Harvard Business Review, March-April.

Porter, M. (1998). On competition; Harvard Business Review Book.

Pratheepkanth, P. (2011). Capital Structure and Financial performance: Evidence from Selected Business Companies from Colombo Stock Exchange Srilanka. International Referred Research Journal, 2(2), 171-183.

Roden, O., \& Lewellen, W. (1995). Corporate capital structure decisions: Evidence from leveraged buyouts. Financial Management, 24, 76-87. https://doi.org/10.2307/3665536

Tailab, M. M. (2014). Analyzing Factors Effecting Profitability of Non-Financial U.S. Firms. Res. J. Finance Account, 5, 17-26.

Taub, A. (1975). Determinants of firm's capital structure. Rev. Econ. Stat., 57, 410-416. https://doi.org/10.2307/1935900

Xu, Mou \& Bachuenvijt W. (Unpublished). Factors Affecting Financial Performance of Firms Listed On Shanghai Stock Exchange 50(SSE 50). Retrieved June 10, 2017 from http://www.google.com

Yurtoglu, B. B. (2004). Persistence of Firm-Level Profitability in Turkey. Appl. Econ., 36, 615-625. https://doi.org/10.1080/0003684042000217652

\section{Copyright Disclaimer}

Copyright for this article is retained by the author(s), with first publication rights granted to the journal.

This is an open-access article distributed under the terms and conditions of the Creative Commons Attribution license (http://creativecommons.org/licenses/by/3.0/). 